\title{
Potensi Limbah Cangkang Telur dan Daun Tembelekan (Lantana camara L.) Sebagai Salep Antiseptik Alami
}

\author{
Sariyana $^{1 *}$, Andi Nofriani ${ }^{1}$, Hadijah Sabarwati ${ }^{1}$, Sahidin $^{2}$ \\ ${ }^{1}$ Jurusan Kimia FMIPA Universitas Halu Oleo, Kampus Hijau Bumi Tridharma Anduonohu Kendari 93232 \\ ${ }^{2}$ Fakultas Farmasi Universitas Halu Oleo, Kampus Hijau Bumi Tridharma Anduonohu Kendari 93232
}

\begin{abstract}
Abstrak
Salep antiseptik alami dari limbah cangkang telur dan daun tembelekan (Lantana camara L.) diformulasikan untuk penyembuhan luka. Salep dibuat dengan kombinasi serbuk cangkang telur dan ektrak kental daun tembelekan dengan konsentrasi 5\%, 10\%, 15\%, dan 20\%. Pengujian potensi salep sebagai antiseptik dilakukan secara in vitro dan in vivo. Uji secara in vitro dilakukan pada 2 jenis bakteri yaitu Staphylococcus aureus dan Eschericia coli. Uji secara in vivo dilakukan pada tikus putih galur Wistar sebanyak 14 ekor yang diberi luka sayat sebesar $1,5 \mathrm{~cm}$ selama 8 hari, dimana diameter penyembuhan luka dianalisis dengan menggunakan metode ANOVA (Analysis Of Variant). Hasilnya uji in vitro memperlihatkan bahwa salep memiliki aktifitas anti bakteri yang ditandai dengan terbentuknya zona bening yang semakin meningkat seiring dengan peningkatan konsentrasi. Hasil uji in vivo menunjukkan bahwa salep efektif dalam menyembuhkan luka, dimana semakin tinggi konsetrasi semakin cepat pula proses penyembuhan luka. Hasil ini menunjukkan bahwa limbah cangkang telur dan daun tembelekan menjadi bahan yang menjanjikan untuk salep antiseptik alami terhadap penyembuhan luka.
\end{abstract}

Kata kunci: Cangkang telur, Lantana camara, salep, antiseptik

\section{Pendahuluan}

Meningkatnya aktivitas sehari-hari tidak bisa terhindarkan dari kecelakaan, salah satu akibat yang ditimbulkan dari kecelakaan tersebut ialah timbulnya luka. Luka didefinisikan sebagai keadaan robek atau terkoyaknya sejumlah jaringan tubuh, baik itu jaringan kulit, jaringan oiot, jaringan saraf, pembuluh darah dan limfa oleh beberapa faktor [1].

Efek yang ditimbulkan akibat luka sangat bervariasi, mulai terjadinya proses pendarahan, hingga timbulnya infeksi akibat kontaminasi bakteri pada daerah luka. Proses penyembuhan luka atau penutupan luka perlu dilakukan secepatnya untuk mencegah berkembangnya bakteri dengan cepat karena semakin basah luka tersebut akan menyebabkan lamanya penyembuhan luka. Penyembuhan luka dapat dipercepat dengan zat yang dapat mengeringan luka dengan cepat dan zat yang dapat mencegah munculnya tumbuhnya bakteri pada luka. Zat tersebut dapat berasal dari bahan kimia sintesis ataupun berasal dari bahan alami. Salah satunya cangkang telur, di Indonesia diperkirakan setiap tahunnya terdapat sekitar 75.112 ton limbah kulit telur ayam peternak dan 18.620 ton limbah kulit telur ayam kampung [2].

Cangkang telur dapat berfungsi mempercepat penyembuhan luka karena tersusun atas senyawa protein sederhana dan kalsium, yaitu kalsium karbonat sekitar 95\% [3]. Kandungan kalsium dan senyawa protein sangat penting perananya dalam penyembuhan luka. Kalsium akan membantu protrombin dalam membentuk benang-benang fibrin ketika luka mengeluarkan enzim trombokinase. Selain kalsium pada cangkang telur juga terdapat memran telur yang juga berperan penting pada proses penyembuhan luka, membran telur mengandung zat aktif seperti kolagen, glukosamin, asam hialuronat, kondroitin sulfat dan protein-protein sulfur, yang berperan penting pada berbagai fungsi sel termasuk fibrolas untuk meningkatkan produksi kolagen sehingga mampu mempercepat penyembuhan luka. Selain itu memran telur juga dapat meredahkan dan mengurangi rasa nyeri dengan adanya kandungan glukosamin dan kondroitin yang dimiliki oleh memran kulit telur ayam [4].

*Email: $\underline{\text { oka_sariyana@yahoo.com }}$ 
Alternatif lain yang dapat digunakan dalam penyembuhan luka yaitu Lantana camara atau daun tembelekan yang mengandung senyawa kimia alkaloid, flavonoid, lemak,saponin, tannin, protein, senyawa fenolik dan minyak atsiri [5]. Adanya kandungan senyawa kimia tanin, flavonoid dan saponin pada daun tembelekan dapat berfungsi sebagai senyawa antibakteri sehingga dapat digunakan untuk mempercepat penyembuhan luka dan mencegah infeksi yang kemungkinan akan terjadi akibat bakteri.

\section{Bahan dan Metode}

\subsection{Umum}

Jenis penelitian yang digunakan adalah penelitian eksperimen, yang dilakukan di Laboratorium Fakultas Farmasi Universitas Halu Oleo. Daun tembelekan diperoleh dari wilayah Kota Kendari. Bakteri S. aureus dan E. coli, serta tikus galur Wistar diperoleh dari Laboratorium Farmasi Universitas Halu Oleo. Sampel limbah cangkang telur diperoleh di berbagai rumah makan sekitar kampus baru UHO kelurahan Lalolara Kecamatan Kambu, Provinsi Sulawesi Tenggara.

\subsection{Preparasi Sampel dan Ekstraksi}

Limbah cangkang telur ayam dibersihkan dan direndam dengan menggunakan air panas, dan selanjutnya dikeringkan dalam oven pada suhu $105^{\circ} \mathrm{C}$ selama 30 menit. Setelah kering, cangkang telur dihaluskan dengan blender sampai menjadi serbuk yang halus. Lalu, serbuk cangkang telur diayak dengan ukuran 250 mesh.

Sampel daun tembelekan dikeringkan tanpa terkena sinar matahari langsung. Sampel yang kering kemudian dihaluskan sampai berbentuk serbuk. Sebanyak $100 \mathrm{~g}$ sampel dimasukkan dalam wadah dan dimaserasi selama 1 x 24 jam dengan pelarut metanol. Hasil ekstraksi kemudian disaring, dan filtrat yang diperoleh dikentalkan menggunakan alat rotavapor sampai ekstrak tidak mengandung pelarut.

\subsection{Pembuatan Salep}

Formula salep dibuat dengan menggunakan adeps lanae $15 \mathrm{~g}$ dan vaselin album $85 \mathrm{~g}$ [6]. Peleburan basis salep dilakukan dengan penambahan alkohol sambil terus diaduk hingga homogen. Pembuatan salep ekstrak cangkang telur dan daun tembelekan dilakukan dengan cara yang sama yaitu basis salep yang ditambahkan dengan alkohol dan ditambahkan ekstrak sedikit demi sedikit hingga homogen dan membentuk salep. Sediaan salep yang akan dibuat dalam penelitian ini memiliki konsentrasi ekstrak cangkang telur dan daun tembelekan yaitu $5 \%, 10 \%, 15 \%$, dan $20 \%$. Rancangan formula disajikan dalam tabel berikut.

Tabel 1. Formula salep

\begin{tabular}{lcccc}
\hline \multirow{2}{*}{ Bahan } & \multicolumn{4}{c}{ Konsentrasi } \\
\cline { 2 - 5 } & $5 \%$ & $10 \%$ & $15 \%$ & $20 \%$ \\
\hline Cangkang telur & $2 \mathrm{~g}$ & $4 \mathrm{~g}$ & $6 \mathrm{~g}$ & $8 \mathrm{~g}$ \\
Ekstrak daun tembelekan & $2 \mathrm{~g}$ & $4 \mathrm{~g}$ & $6 \mathrm{~g}$ & $8 \mathrm{~g}$ \\
Basis salep & $38 \mathrm{~g}$ & $36 \mathrm{~g}$ & $34 \mathrm{~g}$ & $32 \mathrm{~g}$ \\
m.f.Ungt & $40 \mathrm{~g}$ & $40 \mathrm{~g}$ & $40 \mathrm{~g}$ & $40 \mathrm{~g}$ \\
\hline
\end{tabular}

\subsection{Uji Aktivitas Antibakteri Secara In Vitro}

Uji aktivitas antibakteri secara in vitro menggunakan metode difusi agar (difusi Kirby dan Bauer yang dimodifikasi). Larutan uji salep kombinasi cangkang telur ayam, membran telur ayam dan daun tembelekan dengan berbagai konsentrasi $(10 \%, 20 \%$ dan $30 \%$ ), akuades sebagai kontrol negatif; larutan ciprofloxacin $50 \mu \mathrm{g} / 50 \mu \mathrm{l}$ sebagai kontrol positif; masing-masing diteteskan pada sumur yang berbeda sebanyak $50 \mu \mathrm{l}$. Kemudian cawan petri berisi media, bakteri, dan sampel uji diinkubasi suhu $37^{\circ} \mathrm{C}$ selama $1 \times 24$ jam. Zona bening yang terbentuk diukur sebagai zona hambat pertumbuhan bakteri.

\subsection{Uji Aktivitas Antibakteri Secara In Vivo}

Hewan uji yang digunakan dalam penelitian ini ialah tikus putih jantan galur Wistar sebanyak 14 ekor dengan berat badan 260-280 g. Sebelum pembuatan luka, tikus diaklimatisasi selama 6 hari. Sehari sebelum pembuatan luka, hewan uji dicukur bulunya didaerah punggung sampai licin kemudian dibersihkan dengan alkohol 70\%. Selanjutnya dibuat luka sayatan dengan ukuran panjang $1,5 \mathrm{~cm}$. Perlakuan dan pengamatan atau pengumpulan data pada penelitian ialah sebagai berikut:

a. Tikus putih jantan dibuat luka, kemudian diukur luas luka awal sebelum dilakukan perlakuan.

b. Masing-masing tikus putih jantan diberi perlakuan sebagai berikut :

- Perlakuan A: Luka tanpa perlakuan

- Perlakuan B: Luka diberi dasar salep

- Perlakuan C: Luka diberi Betadine salep

- Perlakuan D: Luka diberi salep ekstrak cangkang telur, membran telur dan daun tembelekan 5\%

- Perlakuan E: Luka diberi salep ekstrak cangkang telur, membran telur dan daun tembelekan $10 \%$

- Perlakuan F: Luka diberi salep ekstrak cangkang telur, membran telur dan daun tembelekan $15 \%$ 
- Perlakuan G: Luka diberi salep ekstrak cangkang telur, membran telur dan daun tembelekan $20 \%$

- Dilakukan pengamatan selama 8 hari untuk melihat diameter penutup luka.

\subsection{Analisis Data}

Pengukuran rata-rata diameter luka terbuka dilakukan dengan $\mathrm{dx}(1,2,3)$ yaitu diameter luka terbuka setiap ulangan perlakuan. Dihitung dengan rumus:

$$
\mathrm{dx}=\frac{d x(1)+d x(2)+d x(3)}{3} .
$$

untuk rata-rata diameter luka terbuka $(\mathrm{cm})$. Secara statistik data dianalisis dengan metode ANOVA (Analysis Of Variant) dengan $\alpha 0,05$ atau 5\%, dengan rumus:

$$
\mathrm{P} \%=x=\frac{\mathrm{do}-\mathrm{dx}}{\mathrm{do}} x 100 \%
$$

dimana P \% untuk persentase penyembuhan luka

\section{Hasil dan Pembahasan}

Preparasi bertujuan untuk memperoleh serbuk cangkang telur agar dapat dikombinasikan dengan ekstrak daun tembelekan (Lantana camara L.) pada proses pembuatan salep. Perendaman menggunakan air panas pada proses ini bertujuan untuk melunakkan cangkang telur sedangkan tujuan dilakukan pengovenan agar diperoleh cangkang telur yang kering sehingga mempermudah dalam proses penghalusan dan penyaringan. Tujuan preparasi sampel adalah untuk menghindari komponen lain dan mengurangi kadar air yang dapat menyebabkan rusaknya sampel akibat susunan senyawa dalam yang berubah karena reaksi enzimatis. Sebanyak $100 \mathrm{~g}$ serbuk daun $L$. camara dimaserasi dengan merendam serbuk sampel daun tersebut ke dalam pelarut metanol.

Sediaan salep dibuat dalam konsentrasi ekstrak kental daun tembelekan dan serbuk cangkang telur yang berbeda-beda, yaitu 5\%,10\%, 15\% dan 20\% sebanyak $40 \mathrm{~g}$ untuk 2 kali pemakaian dalam sehari selama 8 hari pengamatan. Formulasi bahan salep dengan variasi konsentrasi yang berbeda bertujuan untuk melihat pengaruh tingkat konsentrasi bahan terhadap proses penyembuhan luka. Pada prosesnya terlebih dulu ekstrak kental daun tembelekan dilarutkan menggunakan metanol kemudian ditambahkan sedikit vaselin album hingga homogen, hal ini bertujuan ekstrak kental dan serbuk tidak bereaksi. Setelah homogen ditambahkan serbuk cangkang telur yang dilanjutkan dengan penambahan vaselin album sampai tercampur rata hinggga diperoleh produk yakni salep antiseptik alami.

Pengujian aktivitas antibakteri secara in vitro dilakukan pada dua jenis bakteri yakni Staphylococcus aureus dan Escherichia coli dengan Ciprofloxacin sebagai kontrol positif dan vaselin album sebagai kontrol negatif. Pengujian pada kedua jenis bakteri tersebut digunakan media padat berupa nutrien agar sintesis dengan komposisi $20 \mathrm{mg} / 1000 \mathrm{~mL}$. Suspensi bakteri dibuat menggunakan $\mathrm{NaCl}$ fisiologi dimana berfungsi untuk makhluk hidup. Hasil pengujian tersebut dapat dilihat pada gambar berikut.
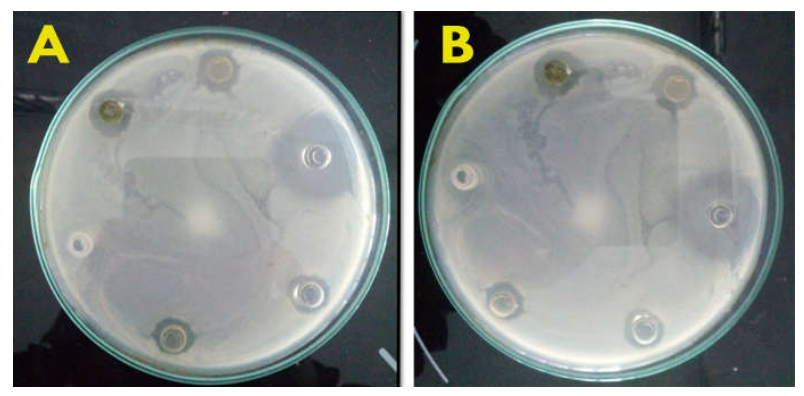

Gambar 1. Pengujian aktivitas salep terhadap bakteri, $S$. aureus (a); dan E. coli (b)

Tabel 1. Hasil Uji Antibakteri secara in vitro

\begin{tabular}{ccccccc}
\hline \multicolumn{3}{c}{$\begin{array}{c}\text { Konsen } \\
\text { trasi } \\
(\%)\end{array}$} & \multicolumn{5}{c}{$\begin{array}{c}\text { S. aureus } \\
(\mathrm{mm})\end{array}$} & $\mathrm{I}$ & $\mathrm{II}$ & III & I & II & III \\
\cline { 2 - 7 }$(\%)$ & & 27 & 28 & 27 & 26,25 \\
$\begin{array}{c}\text { Kontrol } \\
(+)\end{array}$ & 25 & 24 & & & & \\
$\begin{array}{c}\text { Kontrol } \\
(-)\end{array}$ & - & - & - & - & - & - \\
5 & 11,25 & 11,5 & 11,25 & 10 & 10,5 & 11 \\
10 & 12,25 & 13,5 & 11,27 & 13,75 & 13,5 & 11,75 \\
15 & 13,5 & 13,75 & 14,76 & 15 & 14,25 & 14 \\
20 & 13,75 & 16 & 15,75 & 15 & 14,4 & 15 \\
\hline
\end{tabular}

Pengujian pada kedua jenis bakteri tersebut menunjukkan bahwa baik pada cawan petri I, II maupun III, semakin besar konsentrasi kombinasi salep maka semakin luas diameter media hambat bakteri atau semakin banyak bakteri yang dihambat.

Hasil pengukuran rata-rata panjang luka untuk semua kelompok perlakuan pada hari ke-1 sampai hari ke-8 memperlihatkan perubahan panjang luka berkurang paling signifikan dengan konsentrasi $20 \%$ dibandingkan kelompok perlakuan lainnya. Salep tersebut mengandung zat aktif yang mampu meningkatkan aliran darah ke daerah luka dan juga dapat menstimulasi fibroblast sebagai respon untuk penyembuhan luka. Sebaliknya daya penyembuhan luka terbuka pada tikus putih jantan paling rendah terdapat pada luka tanpa perlakuan dan dasar salep. Selain itu, kemampuan salep 
untuk mencegah infeksi membantu penyembuhan luka dengan efektif.

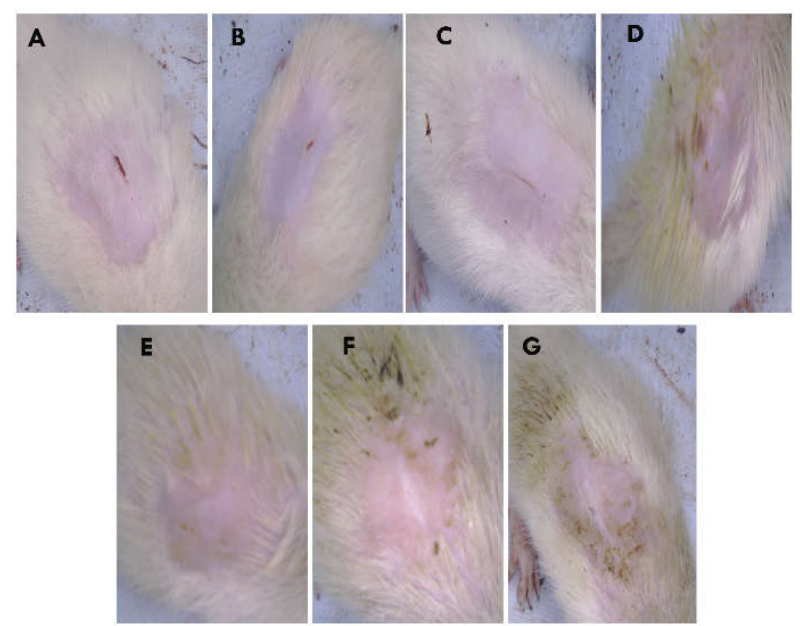

Gambar 2. Pengujian aktivitas penyembuhan luka sediaan salep terhadap tikus jantan; a) Tanpa perlakuan, b) Betadin salep, c) Vaselin album, d) salep 5\%, e) salep 10\%, f) Salep $15 \%$, g) Salep 20\%

Tabel 2. Hasil pengukuran panjang luka tikus jantan

\begin{tabular}{|c|c|c|c|c|c|c|c|}
\hline \multirow[b]{2}{*}{$\begin{array}{l}\text { Hari } \\
\text { ke- }\end{array}$} & \multicolumn{7}{|c|}{ Panjang Luka (cm) } \\
\hline & LTP & $\mathrm{KN}$ & KP & $\begin{array}{c}\text { SAL } \\
\text { CT } \\
\text { DT } \\
5 \%\end{array}$ & $\begin{array}{c}\text { SAL } \\
\text { CT } \\
\text { DT } \\
10 \% \\
\end{array}$ & $\begin{array}{c}\text { SAL } \\
\text { CT } \\
\text { DT } \\
15 \%\end{array}$ & $\begin{array}{c}\text { SAL } \\
\text { CT } \\
\text { DT } \\
20 \%\end{array}$ \\
\hline 1 & 1,5 & 1,5 & 1,5 & 1,5 & 1,5 & 1,5 & 1,5 \\
\hline 2 & 1.5 & 1,5 & 1,3 & 1,5 & 1,5 & 1,4 & 1,3 \\
\hline 3 & 1,4 & 1,4 & 1,2 & 1,5 & 1,3 & 1,2 & 1,2 \\
\hline 4 & 1,1 & 1 & 0,8 & 1 & 0,9 & 0,9 & 0,8 \\
\hline 5 & 1 & 0,9 & 0,7 & 0,7 & 0,6 & 0,6 & 0,6 \\
\hline 6 & 0,8 & 0,6 & 0,4 & 0,6 & 0,4 & 0,3 & 0,4 \\
\hline 7 & 0,6 & 0,5 & 0,3 & 0,3 & 0,2 & 0,1 & 0 \\
\hline 8 & 0,5 & 0,4 & 0,3 & 0,2 & 0 & 0 & 0 \\
\hline
\end{tabular}

Ket: LTP : Luka Tanpa Perlakuan

$\mathrm{KN}$ : Kontrol Negatif

KP : Kontrol Positif

Hasil pengujian ANOVA dengan menggunakan uji F menunjukan nilai $F_{\text {hitung }}$ sebesar 2,98 dan signifikansi 9,35. Nilai $F_{\text {hitung }}$ lebih besar dari $F_{\text {tabel }}(2,98>2,45)$, sehingga dapat disimpulkan rata-rata perlakuan untuk panjang luka terbuka hari ke-1 sampai ke-8 $(\mathrm{cm})$ ada perbedaan nyata dan terbukti secara sistematik. Waktu yang diperlukan untuk proses penyembuhan luka dengan sediaan relatif sama dengan kelompok kontrol positif, tetapi berbeda untuk kontrol negatif dan luka tanpa perlakuan. Hal ini dipengaruhi oleh bahan aktif yang terkandung dalam daun tembelekan yang dapat menghambat pertumbuhan dinding sel bakteri [7]. Selain itu, kandungan kalsium karbonat $\left(\mathrm{CaCO}_{3}\right)$ dan glukosamin pada cangkang telur merupakan berfungsi meningkatkan produksi asam hialuronat pada fase proliferasi penyembuhan luka. Glukosamin juga terlibat dalam proses stimulasi sintesis glikosaminoglikan dan kolagen pada penyembuhan luka [8]. Basis salep berlemak vaselin album yang dapat menarik lebih banyak air sehingga luka cepat kering, tidak membusuk dan menutupi luka [9]. Hasil dari data diatas dapat disimpulkan bahwa salep antiseptik limbah cangkang telur dan daun tembelekan mempunyai efek sebagai penyembuhan luka terbuka pada kulit tikus putih jantan.

\section{Kesimpulan}

Salep antiseptik alami dari limbah cangkang telur dan daun tembelekan dapat digunakan sebagai salah satu inovasi dalam penanggulangan luka untuk mencegah proses pendarahan dan infeksi.

\section{Daftar Pustaka}

1. Abdurrahmat AS. Luka, Peradangan dan Pemulihan. Jumal Entropi, 2014, Vol. 9(1).

2. Stadelman WJ, Cotteril OJ. Egg Science and technology. The AVI Publising Company: Connecticut, 1972.

3. Warsy, Chadijah S, Rustiah W. Optimalisasi Kalsium Karbonat dari Cangkang Telur untuk Produksi Pasta Komposit. Jurnal Al-Kimia, 2013 Vol. 4(2).

4. Ruff KJ, Endres JR, Clewell AE, Szabo JR, Schauss AG. Safety Evaluation of A Natural Eggshell Membranederived Product. Food Chem. Toxicol., 2012, 50(3-4); 604-11.

5. Tolanamy ES, Patadjai RS, Nur I. Potensi Ekstrak Daun Tembelekan Lantana camara sebagai Penghambat Tumbuh Bakteri pada Rumput Laut. Jurnal Sains dan Inovasi Perikanan. 2017, Vol. 1(1); 1-8.

6. Ningsih DR, Zusfahair, Kartika D. Identifikasi Senyawa Metabolit Sekunder Serta Uji Aktivitas Ekstrak Daun Sirsak Sebagai Antibakteri. Molekul, 2016, Vol. 11(1); 101-11.

7. Djide NM, Sartini. Dasar-dasar Mikrobiologi Farmasi. Makassar: Lembaga Penerbitan Unhas, 2008.

8. Novitasari AIM, Indraswary R, Pratiwi, R. Pengaruh Aplikasi Gel Ekstrak Membran Kulit Telur Bebek 10\% Terhadap Kepadatan Serabut Kolagen pada Proses Penyembuhan Luka Gingiva. ODONTO: Dental Journal, 2017, Vol 4(1).

9. Anief M. Farmasetika, Cetakan IV, Yogyakarta: Gadjah Mada University Press, 2007. 